\title{
Accommodations in Teacher Education: Perspectives of Teacher Candidates with Learning Disabilities and their Faculty Advisors
}

\author{
Karen Csoli \& Tiffany L. Gallagher \\ Brock University
}

\begin{abstract}
This study of teacher candidates with learning disabilities profiles their experience in a teacher education program. Two teacher candidates and their faculty advisors offer perspectives at various points during the teacher education program. Findings indicate that the teacher candidates were able to complete their required courses when their professors facilitated appropriate accommodations for them. In their elementary classroom practica, the participants thrived when teaching in their trained discipline or content area, but often needed scaffolding from teacher associates when teaching mathematics and reading. Prior to disclosing their disability to their teacher associates, the teacher candidates attempted to gauge their mentors' tolerance of learning disabilities. Based on their lived experiences, the participants held distinct beliefs about integration and reducing the stigma of learning disabilities. Discussion on the implications for teacher education and support of teacher candidates with learning disabilities is offered.
\end{abstract}

Individuals with learning disabilities are entering teacher education programs in expanding numbers (Baldwin, 2007; Leyser \& Greenberger, 2008; Papalia-Berardi, Hughes, \& Papalia, 2002). With the advent of the Accessibility for Ontarians with Disabilities Act (2005), teacher education programs in Ontario are faced with the challenge of supporting teacher candidates with learning disabilities while at the same time ensuring that these candidates are able to demonstrate completion of the essential criteria required of a teacher. Supporting teacher candidates with learning disabilities involves a number of stakeholders: the teacher candidates themselves, the faculties of education, the colleges of teachers, teacher associates, and the students in the practica classrooms. The literature to date has focused on a mixture of experiences of persons with learning disabilities as students, student teachers, and/or as teachers (Ferri, Keefe, \& Gregg, 2001; Pope, Bowman, \& Barr, 2001; Riddick, 2003), and attitudes towards teacher candidates with learning disabilities (Baldwin, 2007; Leyser \& Greenberger, 2008; Reilly et al., 1998). While there has been a mixture of experiences, providing accommodations in the coursework for teacher candi- 
dates has not risen as a contentious issue (Baldwin, 2007; Leyser \& Greenberger, 2008). However, Baldwin (2007) identified providing accommodations during the practica placement as an issue that directors of education consider to be unethical. This essential aspect of teacher education is still not well understood from the perspectives of teacher candidates with learning disabilities or from the viewpoints of their faculty advisors. Therefore, the purpose of this study was to gain insights into the practicum experiences of teacher candidates with learning disabilities from their perspective and those of their faculty advisors.

\section{Teacher Education}

Teacher education programs seek to apply current theory and research to assist teacher candidates in developing and implementing personal conceptions of teaching into practice (Gitlin, Barlow, Burbank, Kauchak, \& Stevens, 1999; Kim \& Hannafin, 2008; Loughran, 2006). Research indicates that candidates' existing beliefs about teaching and learning greatly influence their teaching practice and are difficult to change in teacher education programs (Fellows, 1993; Jensen, 2001). Usually, their childhood school experiences have more influence over their teaching methods than their teacher education experiences (Fellows, 1993; Loughran, 2006; McMahon, 1997; Roskos \& Walker, 1994). Most teacher candidates are a product of their past and their own student observations of teaching, which may be due to the number of years spent being a pupil as compared to those spent as teacher candidates (Loughran, 2006; Swafford, Peters, \& Lee, 1998; Wham, 1993). For teacher candidates with learning disabilities, their experiences as pupils may have been particularly challenging. Thus, their lived experiences as students and as teacher candidates are essential to understanding their teaching practice (van Manen, 1997).

\section{Faculty Supervision in Teacher Education}

In many teacher education programs, teacher candidates are supervised in their teaching practica or field placement by an advisor or supervisor who is associated with the education college. This field-based advisement process may include classroom observations of the teacher candidate, debriefing sessions between advisors and teacher candidates, and/or meetings with the teacher associates (Freidus, 2002). The goals of faculty supervision are to help teacher candidates understand how their teaching is informed by theory and research, and to encourage them to be reflective (Loughran, 2006). It is often challenging to get teacher candidates to make connections between their beginning practice and theory-but in doing so, faculty advisors push them to develop as reflective practitioners (Schön, 1983). In this fashion, the faculty advisor is facilitating the bridge between the teacher education program and the classroom by scaffolding the teacher candidates' learning so that they may interpret their experiences and refine their understandings.

\section{Teachers and Candidates with Learning Disabilities}

Research on the experiences of teacher candidates and teachers with learning disabilities has focused on their experiences both as students and as teachers, the attitudes of students and faculty, issues of disclosure, and practica experiences. Many teachers and teacher candidates with learning disabilities recall experiences of stigma within their peer circles in elementary and secondary schools (Ferri et al., 2001; Riddick, 2003). This stigma has been described as resulting from the social isolation many felt from being pulled out of class to receive support (Ferri et al., 
2001) and from the low academic expectations of their teachers (Ferri et al., 2001; Riddick, 2003). In some cases, this was a motivating factor to become a teacher. Riddick's (2003) teacher participants were frustrated that they were underestimated at school and many wanted to give students a better experience than they had, while one of Ferri et al.'s (2001) participants reported that "[she didn't] want [her] students to go through what [she] went through" (p. 27). In fact, Ferri et al. speculate that their participants countered this stigma as adults by overcompensating as teachers, becoming perfectionists in their profession, and believing they must perform better than other teachers.

Teachers with learning disabilities may pursue teaching as a profession based on their belief in an ethic of care for students. In particular, when teachers with learning disabilities work with students with special needs, they are able to relate to these students and share their experiences, thus, creating a unique bond with them (Ferri et al., 2001; Riddick, 2003). The personal past school experiences of teachers with learning disabilities allows them to relate to their students with learning disabilities as they understand their students' needs and can improve student motivation (Ferri et al., 2001). The lived experience of having a learning disability affords these teachers with an understanding of the importance of how fundamentally significant the appropriate placement of students with disabilities is within a school.

Yet it is still common in educational settings for stigmas to exist with regard to the competency of a teacher with a learning disability and as such, negative attitudes continue to be a barrier for all teachers with disabilities (Pope et al., 2001). In the field, stereotypes may be held by fellow teachers, students, parents, and administrators. For example, Reilly et al. (1998) found that a teacher who discloses a learning disability elicits less favourable evaluations on measures of lecture delivery, rapport, organization, content, confidence, and global quality from students than a teacher with a visible physical disability or reporting no disability at all. Teacher candidates with learning disabilities may also experience mixed reactions in their teacher education programs. Most faculties of education report positive attitudes towards candidates with disabilities and learning disabilities (Baldwin, 2007; Leyser \& Greenberger, 2008); however, this does not translate to all aspects of the program, particularly, the practica or field placement. Baldwin (2007) found that many directors of teacher education programs believe that classroom accommodations for teacher candidates with learning disabilities are acceptable; however, when teachers were required to demonstrate their practical knowledge in the field, directors of education considered accommodations to be both ineffective and unethical. The directors believed that practica were not primary barriers to teacher candidates with learning disabilities, yet these same directors also identified the practica as the first place where a teacher candidate with a learning disability encountered problems (Baldwin, 2007). Teacher candidates often encounter problems during practica because accommodations that have been effective in the university classroom do not necessarily transfer to field-based settings (Akins, Chance, \& Page, 2001).

Some teacher candidates choose not to disclose that they have a learning disability and this continues to be one of the challenges in providing support (Leyser \& Greenberger, 2008; Pope et al., 2001; Riddick, 2003). Other teacher candidates evaluate the attitudes of their teacher associates before disclosing during their practica (Riddick, 2003). Many researchers have concluded that teacher educators need more training to teach future professionals with learning disabilities (Baldwin, 2007; Leyser \& Greenberger, 2008; Papalia-Berardi et al., 2002).

While the current research provides various insights into the experiences of teacher candidates with learning disabilities, key considerations of their accommodation experiences have not been examined. For example, while Riddick (2003) and Ferri et al. (2001) explored the experi- 
ences of teachers and teacher candidates as students in the public system, they did not examine their experiences within teacher education programs. The practicum experience of teacher candidates is discussed by both Atkins et al. (2001) and Pope et al. (2001), but neither research team spoke with teacher candidates with learning disabilities during their practica, which is where many experience difficulty (Atkins et al., 2001). Atkins et al. and Papalia-Berardi et al. (2002) both emphasized the necessity for teacher candidates to disclose their learning disability, but only Riddick spoke to this population about their reasons for disclosing or not. Baldwin (2007) identified a lack of consistency in faculty attitudes towards teacher candidates with learning disabilities, but this study only asked about the failures of teacher candidates with learning disabilities, not their accomplishments.

It is essential to understand the factors that help teacher candidates with learning disabilities in teacher education programs in order to better meet their needs. This study documented the experiences of teacher candidates with learning disabilities from different stakeholders' perspectives. This research examined the role of mentor teachers and teacher educators in supporting these teacher candidates. Accordingly, this article speaks directly to both teacher candidates with learning disabilities and teacher educators who support them; recommendations are provided to the latter. Overall, this research sought an understanding of the challenges that teacher candidates encounter and the assistance and accommodations that they receive which makes it possible for them to meet those challenges. Data for this study were derived from a series of interviews with the teacher candidates and their advisors to answer the following research questions:

1) In a teacher education program, what are the experiences of teacher candidates with learning disabilities?

2) What is the role of faculty advisors in supporting teacher candidates with learning disabilities?

\section{Institutional Context}

\section{Method}

This research was situated in a teacher education program within a faculty of education of a university in Southern Ontario, Canada. Teacher candidates enter this 8-month program with a completed undergraduate degree and then take courses in curriculum studies, educational foundations, and professional ethics that focus on one of two divisions (Primary/Junior and Junior/Intermediate or Intermediate/Senior). Practica placements are supported within a cohort led by faculty advisors who supervise teacher candidates in their field placements and provide feedback to candidates to further develop their practice. In a cohort team of faculty advisors, an education professor works with part-time faculty who come to this role with experience as teachers or administrators. Teacher associates are practicing teachers who mentor the teacher candidates within their school placements or practica.

\section{Teacher Candidate Participants}

Potential teacher candidate participants responded to a general call for volunteers to participate in this study. It was specified that participants have a formal identification of learning disability to qualify to participate. Melanie was a 23-year-old teacher candidate with an undergraduate degree in human kinetics. Melanie was diagnosed with a learning disability in reading comprehension, spelling, and math computations when she was in Grade 3. She recalled having positive formative experiences in school and wanted to model herself after a few of her physical education teachers. She received accommodations in both elementary and secondary school, as well as in her undergraduate education. Melanie was in the Junior/Intermediate (grades 4-10) 
stream of teacher education with physical education as her teachable subject. Her first practicum was in a Grade 6 class with 29 diverse students. She was assigned to teach all areas of the curriculum in a portable classroom setting. For her second placement, Melanie had a large Grade 8 class of 33 students and she also taught in a segregated general learning disabilities class.

Glenda was a 37-year-old married mother with one son. She attended three different postsecondary institutions to complete her undergraduate degree in music therapy 10 years prior to entering teacher education. Her husband had been a teacher for over a decade and encouraged her to pursue teaching. Glenda recalled having a psychoeducational assessment when she was 11 or 12 years old. She noted that organization and "flipping numbers and letters" were a part of her learning disability. Glenda was also in the Junior/Intermediate stream of teacher education with music as her teachable subject. Her first placement was in a Grade 4 classroom in a country school and her second placement was in an intermediate classroom (Grade 7/8).

\section{Faculty Advisor Participants}

Bill and Lawrence were faculty advisors for Melanie. Bill was a part-time faculty member with several years of experience as an elementary school principal. He began working at the university upon retirement and had worked for almost a decade as a faculty advisor. Lawrence was a full-time faculty member in his second year as a faculty advisor. Formerly, Lawrence held faculty positions at other institutions teaching in his area of specialization, assessment and evaluation.

Marie was one of Glenda's faculty advisors. Marie was also a full-time faculty member with French education as her area of specialty. Marie had several years of experience as a school board consultant before coming to the faculty of education. She had been a faculty advisor for 3 years.

\section{Data Collection and Analysis}

The primary method of data collection was one-on-one interviews with one of the authors. Interviews were approximately 1 hour in duration and were audio-recorded. Interview protocols were devised and provided to the participants in advance, along with all research ethics consent documents. For the two teacher candidates, the interview questions attempted to elicit responses related to their perspectives on their learning disability and their accommodation strategies: "Describe the nature of your LD along with the learning strategies that work well for you." They were asked to describe their placements and disclosure of their learning disabilities, "Did you disclose your learning disability? To whom? Why? If yes, how did these individual(s) react and treat you afterwards? If no, then how did not disclosing affect your perceptions of the placement requirements?" As well, they were asked to speculate on what could possibly hinder or help in the participation of teacher candidates with learning disabilities in the teaching profession: "What changes do you think need to happen to support/accommodate/include student teachers with disabilities?" Follow up questions probed teacher candidates to provide specific illustrations and examples of their experiences. Melanie was interviewed three times: prior to and after her first placement, and after her second placement. Glenda was interviewed two times: prior to and after her first placement. She declined an interview after her second placement as she had moved out of the region.

Faculty advisors' interview questions related to their views on supporting teacher candidates with learning disabilities and providing resources and accommodation strategies: "How do you think your teacher candidate with a learning disability accommodated for his/her learning 
disability? What challenges, opportunities, achievements, or weaknesses were identified by you in this process?" Faculty advisors were asked to comment on how prepared they felt to assist teacher candidates with a learning disability and what was needed to accommodate teacher candidates with disabilities in the teaching profession: "How prepared did you feel to assist in accommodating your teacher candidate with a learning disability? What changes if any do you believe would be needed to accommodate teacher candidates with disabilities in the teaching profession?" Probes were made to elicit faculty advisors to make connections between their work with teacher candidates with learning disabilities and other students that they had worked with in the past that had learning disabilities.

The participants' responses were transcribed and data were culled and coded. Coding was done independently by each of the authors. The authors then came together to compare and negotiate their codes. Common categories for the codes emerged from these data and categorical clusters were collapsed to form general patterns (Bogdan \& Biklen, 1998; Creswell, 1998, 2005; Miles \& Huberman, 1994). Meaning was extracted from these general patterns and labelled as themes, which have been articulated in the form of a narrative (Creswell, 1998). This narrative description outlines the perspectives of the participants within a teacher education program year. Various quotations from the transcriptions were identified to encapsulate and illustrate the general patterns or themes. The foci of each theme aimed to respond to one of the research questions. Within the narrative, there are four themes that focus on considerations about disclosure, teacher education coursework, practica, and attitudes about teachers with learning disabilities. The themes were then shared with the participants for further verification.

\section{Findings}

The research questions sought to elucidate the experiences of teacher candidates with learning disabilities and the role of their faculty advisors in supporting them. Four main themes were identified: disclosure, coursework accommodations, practica experience, and beliefs and attitudes. The teacher candidates contemplated disclosure of their learning disabilities at different points in the program; faculty advisors were both the subject and consultant on issues of disclosure. The teacher education coursework required accommodations for which the teacher candidates with learning disabilities had to advocate. Teaching practica proved to be challenging for the teacher candidates with learning disabilities; however, they came to recognize their empathetic teaching approach and instructional efficacy. Finally, the beliefs and attitudes about the acumen of teachers with learning disabilities were expressed by the faculty advisors as their teacher candidates completed the program.

\section{Disclosure or Non-disclosure?}

Melanie and Glenda had to negotiate through junctures of potential disclosure in the teacher education program. They considered whether or not to disclose their learning disability to course instructors, faculty advisors, and teacher associates. As teacher candidates, they felt compelled to disclose to course instructors to receive academic accommodation such as extra time for tests. This process was similar to the process Melanie and Glenda followed in their undergraduate programs, and as such, they were not hesitant about disclosing to these instructorsdisclosure to others, such as teacher associates, was a different consideration.

Disclosure to faculty advisors. There was no established process for disclosing to the faculty advisors or teacher associates, and this was left to the discretion of teacher candidates. 
Glenda could not recall whether or not she explicitly disclosed to her faculty advisors. She assumed that this information was transferred from her student records. Although Melanie was comfortable with disclosing to her faculty advisors, she did receive negative feedback from one:

When I first told her she questioned me as to why I was in the Junior/Intermediate division. She said to me that she thought that I should then be in Primary/Junior division, because I might not be capable of doing math skills at that [higher] level.

This caused Melanie to doubt herself about becoming a teacher:

...which kinda made me feel like I was like, [...] scared I guess cuz [...] now I have this lady telling me that maybe I shouldn't even be in this division, I should be in a different one. I was like, God! (laughs) What am I doing?

Despite this query, Melanie reported that her relationship with her faculty advisor remained positive.

Disclosure to teacher associates. Both Melanie and Glenda felt the need to evaluate their respective teacher associate's receptivity to students with learning disabilities before disclosing their own learning disabilities. Melanie initially chose not to disclose to her first teacher associate and was wary based on "some comments she had made to me about some of our students - her thinking was that they shouldn't be in normal classes and that they should be learning life skills." When Melanie did disclose, she inserted it into conversation as a matter of fact. The teacher associate did not ask any questions or follow up with Melanie.

During her second placement, Melanie had a positive experience disclosing to her teacher associate as she had known this teacher for several years. Melanie reported that this "was the first one out of all my teachers to ask me more in depth what it [the learning disability] was... what accommodations do you get and all that kind of stuff."

Glenda's experience in disclosure to her teacher associates was different. Glenda reflected on her thinking about whether or not to disclose to her teacher associates and expressed great concern:

...who ever are my associate teachers [they] are going to have a heck of a lot of pull on me [...] it's their way or the highway kinda thing. As far as that goes, if they are open minded, if they sort of seem interested in other points of view, that maybe I could bring that into it. If not, I think I may just leave it out and just kind of work with whatever I have.

Glenda decided that she would disclose in the moment, depending on her perception of the teacher associate's receptivity.

The faculty advisors' perspective. The faculty advisors had a different perspective on disclosure than the teacher candidates. In the past, the faculty advisors had difficulty with students who chose not to disclose from the outset of the program. Lawrence recalled that Melanie first disclosed her learning disability to him, and he shared this information with other faculty. Lawrence reflected that the current system is:

.... double-edged sword for these students because not only do they have that conflicting message, but they also have people who are not very supportive of that type of student or aren't very sympathetic to the fact that they have special needs. [Melanie] is analyzing her associate teachers and their motivations, beliefs, and perspectives before she actually can disclose... 
The decision to disclose a learning disability is one that a teacher candidate tempers based on who the audience is: the higher the stakes associated with this audience, the more guarded the teacher candidate tends to be. As well, the teacher candidate perceives and evaluates the personal beliefs and attitudes of who she or he discloses to.

\section{Navigating Teacher Education Courses}

Melanie and Glenda required accommodations for their courses, but these accommodations were not necessarily recommended or put into place for their practica placements. Based on previous experience in post-secondary level courses, Glenda was able to identify that under stressful circumstances, she needs to focus on maintaining self-control. Glenda recognized challenges associated with her learning disability: "time management is a big issue...I don't usually have a problem with that - anything [else that has] to do with my learning disability." During her busy teacher education program, Glenda worked to track and anticipate deadlines. In terms of compensatory strategies, her faculty advisor, Marie, also recognized that Glenda needed support and she discreetly found an empathetic fellow teacher candidate for her to study with. Marie noted that Glenda "interacted with another student who had self-identified...they looked out for each other...I think she felt more comfortable asking questions or working through things when she thought she was with someone who was processing [information] similarly."

Melanie required assistive software to accommodate for her learning disability, but she did not receive this support in a timely manner due to difficulties in coordinating between the two university campuses. She explained that she "will probably [...] have to read most of what I have to read on my own. I could sit and scan all the pages on my Kurzweil but that takes a long time." But without the Kurzweil software, reading was a laborious process: "I started reading everything because you don't know what you are actually going to really need to read. I was up every night reading forever. I couldn't keep doing this as it was taking so long." Lawrence, Melanie's faculty advisor, advocated on her behalf to get this support: "I do know that she had to work harder, not smarter. She had to work harder because of the amount of time that she put into reading those materials was extended because of the lack of support that she received." Despite the previous undergraduate experience of the teacher candidates, advocacy was still essential to navigate through the teacher education courses. In this teacher education program, faculty advisors acted as liaisons among teacher candidates and their peers, student development staff, and other instructors.

\section{Teacher Education Practica}

The teacher education practica posed inherent challenges for Melanie and Glenda. Teacher associate support was an important factor contributing to their accomplishments in addition to teacher candidates' perceptions of their own empathy and instructional efficacy.

Practica challenges and accomplishments. As a mature student, Glenda was able to reflect on her experiences and isolate strategies that she used to accomplish her goal of remaining focused on lesson facilitation. She recognized that she had to be prepared and organized to teach, and she reported that this was tiring. Glenda noted that if she deviated from her lesson plan, "it went terribly bad because I had it in my head but then when you get into a situation, it's not there anymore." She was able to appreciate the dynamic and spontaneous nature of teaching, "I have to respect that and I think the more I get into actually teaching it will be much easier." 
Prior to Melanie's first placement, she expressed both her anticipated achievements and challenges. She was confident in her abilities to draw on her lived experiences as a student with a learning disability who had been taught through different instructional methods. Melanie credited herself as "understanding things in different ways than a lot of people do. So I think I may have a bit more sympathy for kids when they don't understand things." Melanie believed that she should "be able to teach students in a little bit of a different way that might be understandable for students."

Melanie recognized her own challenges in spelling, reading, and mathematics. In particular, before her first teaching practicum, she feared having to spell accurately, read out loud, write on the blackboard, or recall her multiplication tables. Melanie created opportunities to avoid drawing attention to her weaknesses during her instructional delivery:

I was nervous of when [students] asked me how to spell something. Most of the time, I was fairly confident I knew how to spell it and I would spell it for them and then I would walk over and pick up a dictionary go through the dictionary and look to see if I was right. If I was wrong, then I went back up to the kid and said, this is how it's spelled...I was somewhat self-conscious but at the same point in time, none of the kids ever said anything, none of them.... reading that's a little difficult for me...I always got people to read. I never once read out loud to the class even though I'm sure I know I would have been able to because nothing was overly difficult. It made me feel better and I got them involved.

In the end, Melanie did not have to teach math, so her fears were assuaged (her teacher associate did not assign her to teach all curriculum subjects). Melanie also recognized that to ease her task of marking written assignments, she should require that students submit their work electronically so that she could avail herself of technology supports for grading grammar and spelling, but she did not voice this request.

Teacher associate support. Melanie had two distinctly different interactions with her two teacher associates. Although very encouraging, Melanie's first teacher associate offered her little guidance on how to teach. Melanie did not regard this mentor as a good role model as she was negative and overly strict with the Grade 6 students. Melanie experienced dissonance in her understanding of this teacher associate's regard for students: Melanie was treated with respect; however, the elementary students were not. Melanie's confusion reflects her understanding of herself as a student of the teacher associate and not as a potential peer. For her second placement, Melanie had two teacher associates who offered her support and guidance:

The day before I was teaching, he would sit down and go through everything with me...he gave a lot of guidance. There were no expectations on how I had to teach things - I could teach things however I wanted to. I could use my strengths rather than having to figure out how to accommodate into his way of teaching.

Glenda received a great amount of support from her teacher associate and others in the school such as the computer and art teachers. She was careful to determine who she could approach for assistance and seek this kind of instructional support: "I have a network of people that I can work with. I like to have help from especially ones that have been there for 30 yearsthey've got a lot of experience."

Empathy in teaching. Melanie was empathetic to the different reading skill levels of the students in her Grade 7/8 class and she adapted her instructional methods to reflect this: 
I know as a student I hated being called upon for reading because I couldn't do it. So, I made sure to talk to my teacher associate about who were the best students to call on. I learned as I was going which were the ones I knew I could call upon. I always asked for volunteers and if they did put their hand up I would be sure to choose from those ones as well to give them a chance.

During her second practicum, Melanie made a strong connection with some of the students with learning disabilities in the special education class. She especially appreciated their learning needs after working with them in small group settings. Lawrence acknowledged her competency in connecting with students with exceptionalities even in the regular classroom setting by stating, "she did make a point of checking on those students that were identified in that classroom, and she circulated and gave a little bit of extra support to those kids." Consequently, Melanie made an impact on these students. Lawrence perceived that:

The kids feel that she's authentic. She's very comfortable in the way she interacts with the kids, and she's trying to instil in them that we're not all perfect and some of us have strengths and weaknesses in other areas.

Overall evaluation. Glenda reflected positively on her placement and regarded a productive music-integrated curriculum unit as a great accomplishment: "I found that the kids loved that I brought my music into most of the subjects...I brought in songs that had to do with curriculum and within the music I taught them some of the recorder."

Similar to Glenda, Melanie thrived when teaching in her trained discipline: "They said that I'm such a good student teacher. I had taught a unit on flight and science and the students [told me that I] really made science lots of fun and that they learned a lot." Initially, she questioned her abilities to teach due to her learning disability, but,

as I went along, it got better and better. I figured out I learned the stuff as I go. I don't have to know everything to be able to teach...even though I have a learning disability this is still something that I can do.

Melanie's accomplishments were confirmed by both of her faculty advisors. Bill stated that "she did quite well. I gave her "Highly Successful,", and Lawrence confirmed that Melanie would "be a really good teacher because of the way she presents herself in the classroom, and the type of personality she has. She is very easy-going, the kids are at ease, and they're not afraid to ask for help."

In the teaching practica, the teacher candidates faced challenges that could be directly related to their own learning disabilities. Contributing to positive practica experiences were teacher associate support and opportunities to teach in their subject areas of expertise.

\section{Attitudes and Beliefs about Teacher Candidates with Learning Disabilities}

The faculty advisors used personal stories about previous experiences to explain their approaches when working with teacher candidates with learning disabilities. These stories were used to either illustrate or expand upon their views, and at times revealed their attitudes.

Attitudes based on previous experience. Bill, Lawrence, and Marie all expressed their perceptions that there were attitudinal barriers towards teacher candidates with disabilities. Marie observed that faculty members "tend to cover disabilities in a social issue way. You know, one day we will talk about people who have, you know, this disability and that one and this one and this one." In discussing a previous student who encountered difficulties in the program, 
Marie reflected that many of the problems in that situation occurred due to "prejudices against people with disabilities."

Both Marie and Bill spoke about their own difficulties in school and speculated about their own disabilities. For example, Bill remembered:

....sitting in class and staring at windows and I wouldn't have a clue about what's being said. I had a tough time listening to lectures, and any kind of courses that I took I had to read, and read, and read the notes, because I would have to take that and read over, and over, and over again.

These personal experiences with disabilities were used to illustrate both Marie and Bill's empathy for Melanie and Glenda, but also to explain how they overcame their own challenges. Lawrence used stories to help Melanie understand that he did not consider her learning disability an impediment to her achievements:

I said, 'Look I have a friend who is in medical school and has a reading disability.' [I was] trying to let her know that there isn't a stigma attached to it, at least not in my mind. There might be in some people's minds...

Bill, Lawrence, and Marie also indicated that their personal and professional encounters prepared them for teacher candidates with learning disabilities. For example, Marie felt that she was "prepared for Glenda. I saw all the signs and I could anticipate and now I can ask the questions...." Ultimately, Marie had learned to "trust my teacher's gut. Because my teacher's gut instinctively tells me that maybe I should watch this one a little more carefully and make sure he/she is all right."

Beliefs about teacher candidates with learning disabilities. Overall, the teacher candidates and the faculty advisors believed that candidates with learning disabilities could be excellent teachers. Melanie and Glenda expected to find an atmosphere of inclusion as both teacher candidates and as beginning teachers, and to have access to any necessary supports. When speculating on her upcoming placement, Glenda stated that "I don't think it's going to be a bad experience and I think I am going to be able to help everybody else out." Not only did Glenda believe that she would have a positive experience in her placement, but she also believed that she would be able to help other teachers at the school.

The faculty advisors held similar beliefs. Bill's statement that "I can't imagine you would get someone in the profession that would have a major learning disability, or they would never be able to get through university and teachers' college" also reflected Lawrence and Marie's positions. However, when discussing the progress of Melanie and Glenda specifically, the faculty advisors' attitudes were more sceptical and less optimistic about them becoming teachers with learning disabilities. For example, Lawrence thought he was complimenting Melanie when he stated, "she works hard. There's no doubt about. I just think that she'll make a really good teacher. I don't even think she needs to be a special education teacher." Bill had some concern about Melanie's ability to handle the required workload and to teach at an intermediate grade level:

It may be a little bit more of a challenge with her, because certainly the material that she would need to know, would be quite a bit harder than Grade 6. So she might have a bit more of a difficult time with the marking and lesson planning, and all the rest of it. It might be more of a workload than what she's used to doing. 
Marie similarly showed some reserve when she referred to a previous teacher candidate with a physical disability: "Part of me is worrying because, can he do that as a teacher?"

Accommodations for teacher candidates with learning disabilities. The faculty advisors reflected on the difficulty of providing teacher candidates with learning disabilities with the accommodations that they need during the practicum. The university was responsible for providing accommodations for course work, but once students entered practica placements, the employer, the school, and school board become responsible. Marie expressed "frustration when students come in here and [it] appears to be another year of university when in reality it is completely different. [...] They don't know what accommodations to ask for." Lawrence explained that at the time, there was no policy in place to accommodate teacher candidates in their placements, which constitute 11 weeks of their school year. Lawrence highlighted the precarious position of teacher candidates with learning disabilities:

... if they don't pass their teaching blocks, they can't get recommended to the college [of teachers for certification]. So the practica is the most significant component of the pre-service year, and they're not going to get support, unless they negotiate that with the individual school and the board, and they're not in the position of power to negotiate that.

Faculty advisors play an essential role in supporting the needs of teacher candidates with learning disabilities. They held the belief that the teacher candidates could be productive; however, they also held reservations about the nature of providing accommodations during practica.

\section{Discussion}

Ferri et al. (2001) and Riddick (2003) suggested that teacher candidates with learning disabilities are able to identify with students that are struggling in the classroom. They attribute this level of empathy to an authenticated perspective about teaching students with learning disabilities. Teacher candidates expect to be initiated into an inclusive and accommodating program and profession. This expectation is likely to be based on their lived experiences as students with learning disabilities and subsequent beliefs and attitudes about teaching and learning. Belief systems, like other forms of knowledge, are organized around situations (Anderson, 2001). The belief systems with which teacher candidates enter their pre-service year were powerful at shaping their perceptions about teaching and learning. This was especially true of the teacher candidates in this study: their entering beliefs with respect to being a student with a learning disability were based on their lived experiences as one. These beliefs contributed to their future goals to provide highly individualized support for their students who experience learning difficulties.

During their teacher education coursework, these teacher candidates required accommodations, such as reading with assistive technology or a peer mentor. Accommodations for the coursework were reasonably accessible (the exception being Melanie's texts), and there was a lack of stigma associated with receiving them. However, similar to Baldwin (2007), the situation in the field was different: accommodations in the classroom for teacher candidates with learning disabilities need to be facilitated by the teacher associate and in some cases the school principal. For the most part, the teacher candidates received the support that they needed from their classroom-based teacher associate as a teacher candidate. However, although both of these teacher candidates told the interviewers that they struggled with reading and spelling during their public school years, neither one received any specific accommodations (e.g., Kurzweil software), in- 
struction, or advice on how to compensate for their learning disabilities in the classroom. They bore the brunt of the responsibility for accommodating for their learning disabilities during practice teaching with no specific feedback on the appropriateness of their strategies. Faculty advisors recognized a need for support at this stage of the program; however, they were unclear about the precise nature of accommodations that could and should be provided.

For teacher candidates with learning disabilities, the decision to disclose their disability was evaluated in a situational context. In terms of their coursework at the institutional level, the teacher candidates perceived that they were safe to disclose as academic supports were in place. Here they disclosed to their instructors with minimal concerns or reservations. The candidates' faculty advisors bridged the teacher candidates from their teacher education courses to their practica. Within the context of the practica, the teacher candidates varied with respect to comfort level in disclosing and accordingly wavered on when and to whom to disclose. The teacher candidates proceeded with great caution when disclosing to their teacher associates. The candidates based their evaluation of the teacher associates' openness to themselves as potential teachers with learning disabilities on the teacher associates' amenability to students with learning disabilities. This is a relationship in which a teacher candidate might not wish to disappoint a teacher associate who is grading their performance. The high stakes nature of this relationship is likely to be heightened in the mind of the teacher candidate with a learning disability.

It would appear that some attitudinal barriers towards teacher candidates with disabilities still exist, as noted in previous studies (e.g., Pope et al., 2001; Reilly et al., 1998). The faculty advisors recalled examples of this from their previous experiences in the education college with other teacher candidates with some form of disability. These examples were similar to the present in that there were no policies in place to accommodate teacher candidates in their placements. This small sampling of faculty advisors articulated that they had had both personal and professional interactions with teacher candidates with learning disabilities and they were positioned well to support their needs. As former classroom teachers, these faculty advisors had taught students with learning disabilities and they drew on this experience within this postsecondary context. Two of the faculty advisors elaborated on their own academic challenges, speculating on possible undiagnosed learning disabilities.

While the faculty advisors were explicitly supportive, they seemed to hold notions and reservations about the niche and role that their teacher candidates with learning disabilities might hold. One faculty advisor held the assumption that his teacher candidate would make an excellent special education teacher. Another faculty advisor expressed concerns about his teacher candidate with a learning disability teaching the content required at upper elementary levels. The faculty advisors held prior knowledge about individuals with learning disabilities that was based on their experiences with children with learning disabilities. Prior knowledge is significant and salient (Risko, Roskos, \& Vukelich, 2001), and it is difficult to determine when relevant prior knowledge should be applied (Driscoll, 2000). The faculty advisors attempted to make sense of the learning and practice needs of their teacher candidates with learning disabilities, yet to accomplish this, they had to assimilate this information into their beliefs (Fellows, 1993). Making these conceptual shifts may be an especially difficult process for faculty advisors as they may possess deeply entrenched beliefs about models of teaching. This reality might provide fodder for education college administrators who are in a position to choose ideal faculty advisors to work with teacher candidates with learning disabilities. Of particular interest here is the intersection between beliefs about teacher candidates with learning disabilities and lived experiences in teacher education. During the pre-service experience, the teacher candidates attempted to make 
connections between what they knew (lived experiences as students with learning disabilities) and what they were currently learning (teacher education coursework and practica). These teacher candidates with learning disabilities began their studies with their own schemas about how to teach and interpreted their teacher education experiences through this lens. In a similar vein, the faculty advisors were making connections with their previous experiences teaching elementary students with learning disabilities and current experiences teaching teacher candidates with learning disabilities. The critical difference between the faculty advisors and the teacher candidates was that the former expressed affirmative beliefs but did not always act on these beliefs.

\section{Implications for Teacher Education}

In general, effective teacher preparation provides the prefatory knowledge and skills that are necessary for a new teacher to begin to practice. Teacher educators and field-based faculty advisors play an integral role in this process. In an attempt to negotiate existing beliefs while taking on the new role of teacher, the previous experiences of teacher candidates, faculty advisors, and teacher associates must be examined, deconstructed, discussed, filtered, and then integrated with new knowledge and experience (Anderson, 2001; Kagan, 1992; McMahon, 1997; Pajares, 1992; Pearson \& Stephens, 1994).

Increasing numbers of students with learning disabilities are entering faculties of education, and there is no indication that these numbers will decrease (Baldwin, 2007; Leyser \& Greenberger, 2008; Papalia-Berardi et al., 2002). In Ontario, faculties of education are required by the Accessibility for Ontarians with Disabilities Act (2005) to provide appropriate accommodations for teacher candidates with learning disabilities to facilitate completion of their program. The lived experiences of teacher candidates with learning disabilities need to be respected not just for the benefit of the candidate as a future teacher, but also in terms of the richness of knowledge that these experiences can give us about the practica placements themselves. Teacher education programs should make the effort to create situations that facilitate self-awareness of their own beliefs and knowledge in teacher candidates with learning disabilities.

To improve in their role as teachers of teacher candidates with learning disabilities, teacher associates and faculty advisors should be encouraged to examine their own previous lived experiences with persons with learning disabilities. These lived experiences are integral to their understanding of preparing these candidates to become teachers. In confronting their beliefs and attitudes, teacher associates and faculty advisors must also acknowledge any bias and prejudices they may possess towards teachers (as adults) with learning disabilities. To better support teacher candidates with learning disabilities, both teacher associates and faculty advisors should be provided with the knowledge and tools to meet the needs of teacher candidates with learning disabilities in their practica placements.

Suggestions for teacher education programs to support teacher candidates with learning disabilities are: to facilitate positive attitudes towards teacher candidates with learning disabilities in faculty advisors and teacher associates; select teacher associates with positive attitudes towards teacher candidates with learning disabilities; create a clear disclosure process; identify essential criteria of the practica placement (what cannot be accommodated or altered); create policy for accommodations during the practica; and determine appropriate practica accommodations in advance. These last recommendations will require more research into the best accommodation practices for persons with disabilities in teaching placements. 


\section{References}

Accessibility for Ontarians with Disabilities Act. (2005). Toronto, ON: Queen's Printer for Ontario.

Anderson, L. M. (2001). Nine prospective teachers and their experiences in teacher education: The role of entering conceptions of teaching and learning. In B. Torff \& R. J. Sternberg (Eds.), Understanding and teaching the intuitive mind: Student and teacher learning (pp. 187-213). Mahwah, NJ: Lawrence Erlbaum Associates.

Atkins, W., Chance, C., \& Page, F. (2001). Accommodating student teachers with special needs. Paper presented at the Meeting of the Georgia Association of Teacher Educators, Atlanta, GA. ERIC \#ED459575

Baldwin, J. L. (2007). Teacher candidates with learning disabilities: Effective and ethical accommodations. Teacher Education and Special Education, 30(3), 128-141. doi:10.1177/088840640703000302

Bogdan, R. C., \& Biklen, S. K. (1998). Qualitative research for education. Needham Heights, MA: Allyn \& Bacon.

Creswell, J. W. (1998). Qualitative inquiry and research design. Thousand Oaks, CA: Sage.

Creswell, J. W. (2005). Educational research: Planning, conducting, and evaluating quantitative and qualitative research (2nd ed.). Upper Saddle River, NJ: Pearson Education.

Driscoll, M. P. (2000). Psychology of learning for instruction (2nd ed.). Needham Heights, MA: Allyn \& Bacon.

Fellows, N. J. (1993). The importance of reading, writing and talking in preservice teachers' thinking changes. Paper presented at the meeting of the American Educational Research Association, Atlanta, GA. ERIC \#ED361300

Ferri, B. A., Keefe, C. H., \& Gregg, N. (2001). Teachers with learning disabilities: A view from both sides of the desk. Journal of Learning Disabilities, 34(1), 22-32. doi:10.1177/002221940103400103

Freidus, H. (2002). Teacher education faculty as supervisors/advisors/facilitators: Playing multiple roles in the construction of field work experiences. Teacher Education Quarterly, 29(2), 65-76. Retrieved from http://www .teqjournal.org/

Gitlin, A., Barlow, L., Burbank, M. D., Kauchak, D., \& Stevens, T. (1999). Pre-service teachers' thinking on research: Implications for inquiry oriented teacher education. Teaching and Teacher Education, 15(7), 753-769. doi:10.1016/S0742-051X(99)00015-3

Henderson, C. (2001). College Freshmen with Disabilities, 2001: A Biennial Statistical Profile. ERIC \#ED458728

Jensen, J. W. (2001). Teacher candidates' beliefs: Implications for practice. Paper presented at the Annual Meeting of the American Association of Colleges for Teacher Education, Dallas, TX. ERIC \#ED451193

Kagan, D. (1992). Professional growth among preservice and beginning teachers. Review of Educational Research, 62(2), 129-169. doi:10.3102/00346543062002129

Kim, H., \& Hannafin, M. (2008). Situated case-based knowledge: An emerging framework for prospective teacher learning. Teaching and Teacher Education, 24(7), 1837-1845. doi:10.1016/j.tate.2008.02.025

Leyser, Y., \& Greenberger, L. (2008). College students with disabilities in teacher education: Faculty attitudes and practices. European Journal of Special Needs Education, 23(3), 237-251. doi:10.1080 /08856250802130442

Loughran, J. (2006). Developing a pedagogy of teacher education: Understanding teaching and learning about teaching. London, UK: Routledge.

McMahon, S. I. (1997). Using documented written and oral dialogue to understand and challenge preservice teachers' reflections. Teaching and Teacher Education, 13(2), 199-213. doi:10.1016/S0742051X(96)00016-9

Miles, M. B., \& Huberman, A. M. (1994). Qualitative data analysis: A sourcebook of new methods. Beverly Hills, CA: Sage.

Pajares, F. (1992). Teachers' beliefs and educational research: Cleaning up a messy construct. Review of Educational Research, 62(3), 307-332. doi:10.3102/00346543062003307

Papalia-Berardi, A., Hughes, C. A., \& Papalia, A. S. (2002). Teacher education students with disabilities: Participation and achievement factors. Teacher Education and Special Education, 25(1), 23-31. doi:10 $.1177 / 088840640202500105$ 
Pearson, P. D., \& Stephens, D. (1994). Learning about literacy: A 30-year journey. In R. B. Ruddell, M. R. Ruddell, \& H. Singer (Eds.), Theoretical models and processes of reading (4th ed., pp. 22-42). Newark, DE: International Reading Association.

Pope, C. A., Bowman C. A., \& Barr, K. (2001). Conversations from the commissions: Negotiating the tensions in the preparation of teachers with disabilities. English Education, 33(3), 252-256. Retrieved from http://www.ncte .org/journals/ee

Reilly, N. P., Wennet, C., Murphy, M., Thierauf, M., Gaugler, G., \& Godfrey, K. J. (1998). Teaching evaluation of persons with disabilities differ according to the nature of disability. Journal of Rehabilitation, 64(1), 38-41. Retrieved from http://nationalrehabvaassoc.weblinkconnect.com/cwt/external/wcpages /membership/publications_and_journals.aspx

Riddick, B. (2003). Experiences of teachers and trainee teachers who are dyslexic. International Journal of Inclusive Education, 7(4), 389-402. doi:10.1080/1360311032000110945

Risko, V. J., Roskos, K., \& Vukelich, C. (2001). Prospective teachers' reflection: Strategies, qualities, and perceptions in learning to teach reading. Reading, Research and Instruction, 41(2), 149-176. doi:10.1080 $/ 19388070209558363$

Roskos, K., \& Walker, B. J. (1994). Learning to teach problem readers: Instructional influences on preservice teachers' practical knowledge. Journal of Teacher Education, 45(4), 279-288. doi:10.1177 /0022487194045004006

Schön, D. (1983). The reflective practitioner: How professionals think in action. New York, NY: Basic Books.

Swafford, J., Peters, T., \& Lee, S. (1998). Understanding preservice teachers' beliefs through autobiographical analysis. National Reading Conference Yearbook, 47, 517-528.

van Manen, M. (1997). Researching lived experience: Human science for an action sensitive pedagogy (2nd ed.). London, ON: The Althouse Press.

Wham, M. A. (1993). The relationship between undergraduate course work and beliefs about reading instruction. Journal of Research and Development in Education, 27(1), 9-17. ERIC \#EJ478564

\section{Authors' Note}

Correspondence concerning this article should be addressed to Karen Csoli, Brock University, 500 Glenridge Ave., St. Catharines, ON, L2S 3A1. Email: karen.csoli@brocku.ca 